\title{
DYNAMICS ASSISTANCE FOR LEARNING PANDEMIC TIME COVID-19 IN TUKMUDAL VILLAGE, SUMBER CIREBON
}

\section{Taufik Ridwan}

IAI Bunga Bangsa Cirebon

Email: taufikridwan98@gmail.com

Keywords
The Covid-19
Pandemic,
Learning
Dynamics

Article Info Accepted: July, $3^{\text {rd }} 2019$

Revised: July, $9^{\text {th }} 2019$ Approved: July, $10^{\text {th }} 2019$

\begin{abstract}
Learning is an important instrument to educate the nation's life. As an important system in education, learning is organized as an interaction space for the building of teacher and student relationships to develop cognitive, psychomotor and affective potential. This must be supported by the dynamics of learning that run effectively and an internal learning atmosphere that makes students interested in learning. Learning can also be influenced by external factors, such as the Covid-19 outbreak. The reality shows that the learning dynamics in Tukmudal village are currently being disrupted by the Covid-19 outbreak which has had an impact, including; 1) schools are transferred to homes through an online learning process; 2) there is a transformation of technology-based learning media through the use of Wathshap Group, Zoom, Google Classroom, WebEx, Youtube, and TV channels (TVRI); 3) adjustment of learning methods; 4) adjusting the learning evaluation to determine the standards for class promotion and graduation; and 5) demands for collaboration between parents of students at home as a substitute for teachers to control children's learning.
\end{abstract}

\section{Introduction}

Learning is actually carried out through teacher interaction with students in a learning environment (Mansyur, 2020). The essence of this learning is the assistance provided by educators to transmit knowledge to students. Therefore, in simple terms learning can be interpreted as an enlightenment process carried out by the teacher to help students get learning and be able to understand the learning material given. 


\section{Taufik Ridwan}

This paradigm towards the essence of learning has become a classic with the Covid-19 crisis which has changed the paradigm of education and learning in the world. This pandemic crisis has not only attacked the human respiratory organs, but also stopped the organs of the education and learning system that are normally held through face-to-face learning in schools. The whole world is busy with preventing the spread of Covid-19 so that all activities outside the home and offices, including schools, are temporarily closed, are implemented.

Indonesia is one of the countries affected by the plague, making social distancing and physical distancing a policy of limiting social and physical distance which has an impact on stopping the learning process in schools (Fakhruroji, Tresnawaty, Sumadiria, \& Risdayah, 2020). All education operations were closed, even the national exams were under threat. The crisis in sight is underway forcing all components of education to innovate online distance learning or online learning. This is intended so that the learning process continues amid the outbreak of the Covid-19 epidemic.

One learning model that is adaptive to this pandemic situation is online learning because it is done face-to-face distance between educators and students (Jayul \& Irwanto, 2020). Online learning is a learning model that is carried out using technological devices in the midst of the current pandemic. The effectiveness of this learning model is largely determined by the telecommunications network system as the most important supporting device (Al Hakim, n.d.).

Online learning models require the creativity and skills of teachers to use technology (Novita \& Kaligondang, 2021). Students are also expected to be able to access the network of applications used in learning such as Zoom and several other applications. Although it can be a learning support solution in the midst of the Covid-19 pandemic, there are obstacles because other problems arise related to the lack of network access that is not smooth, the burden of data costs for accessing expensive applications, the unpreparedness of teachers to adapt technology, parents who are less synergistic with teachers assisting children to study at home, to students who are emotionally and socially disconnected from other students (Fikri et al., 2021).

Some of these obstacles occur evenly in all regions in Indonesia. In Cirebon Regency, which is one of the largest cities in Region III Cirebon, with the support of advanced development, it is still felt that it is not optimal in terms of implementing online learning during the pandemic due to network factors that arise drown or disappear from the catch of cellphones

Dynamics Assistance For Learning Pandemic Time Covid-19 In 


\section{Taufik Ridwan}

or teacher and student leptops. Thus, online learning in remote areas with minimal network access will be much tougher to do (PRASETIA, 2021). Studies related to the impact of Covid-19 on the dynamics of learning in the world of education in Indonesia are very interesting to review as a form of scientific reading of the current learning phenomenon (Ulfa, 2021).

\section{Method Research}

The research method used in this research is a qualitative method with a descriptive analytical approach where this research method is based on the philosophy of post positivism, natural object conditions, where the researcher is the key instrument, the data collection technique is done by triangulation (combined). This study aims to obtain data on the application of the cantol roudhoh reading method in improving children's reading skills. In essence this research will be studied to obtain data, understand, and describe the application of reading cantol roudhoh in improving children's reading skills in Tukmudal village, Sumber district, Cirebon district.

\section{Result and Discussion}

\section{A. The Nature of Learning}

Learning is related to an interaction process involving teachers and students (Prasetyo \& Zulela, 2021). Learning is carried out continuously to manage the potential of students to acquire knowledge. The process of interaction in learning will run well if creative teachers use various media and methods in learning to stimulate students to learn with good motivation in learning. Sudirman (2004: 45) suggests that learning is a process of change, so that the purpose of a learning process is interpreted as a conscious effort to change aspects of behavior.

The process of achieving change in learning involves the teacher's efforts as enlightening figures who can organize student behavior (Nurillahi, n.d.). Thus, teachers become role models in the behavior of students. To be able to do this, teachers need various supporting tools such as methods in dealing with complex student situations. In line with this, Sutikno (2009: 32) explains that learning is all the efforts made by teachers as educators so that the learning process occurs in students. It is further argued that there are implicitly selecting activities in learning, establishing and developing methods to achieve learning outcomes. 


\section{Taufik Ridwan}

The expected learning outcomes are related to changes in students. Hamalik means that changes in learning involve changes in perceptions and behavior, including behavior improvement. Learning is also defined as a process towards change, but change in the meaning of learning shows certain characteristics, such as; a) changes occur consciously, b) changes are continuous and functional, c) changes are positive fan active, d) purposeful and directed changes, and e) changes in all aspects of behavior.

Of course, the achievement of all the changes mentioned above is largely determined by various important variables in learning. Teaching material factors also greatly determine the interest of students in learning. The teacher's not being creative in packaging teaching materials will lead to the saturation of students following the learning. This is seen in terms of psychological relations, as explained by Ibn Sina that psychologically a subject matter cannot be explained in one way and must be achieved in a way that is in accordance with the psychological development of students. Thus, the delivery of material must be adjusted to the characteristics of the material to balance the relevance of the material and the methods used in learning.

Based on the explanation above, it can be concluded that learning is essentially an effort towards awareness made by teachers to students. Students who change in learning when there are characteristics of change in the sense of continuous and functional awareness in the sense of behavior application (Juwita, 2021). Learners who are aware must be in a positive sense and actively focused on the value of goodness in all aspects of student behavior. In achieving this change is also determined by various variables, including teaching materials that are supported by methods that are relevant to the psychological growth of students.

Teaching materials and methods must be combined with various teacher strategies that are carried out creatively to increase the attractiveness of students in following lessons (Ferdianti, 2021). During the Covid-19 crisis, learning must be done creatively through various online applications (online) or what is known as online learning.

This kind of learning virtualization encourages teachers to more compact teaching materials that are supported by the right method because of the 


\section{Taufik Ridwan}

minimal time and risk of application costs used (RIZKY, 2021). Thus, it is not only the psychological issues of students that must be the focus of the teacher's attention, but teachers and students are in the same psychological situation adapting learning situations that are carried out online or virtual.

\section{B. Learning Objectives}

The whole series of learning leads to the achievement of goals as a direction to obtain maximum results. Therefore, learning objectives must be an important consideration in carrying out learning designs. Theoretically, learning objectives include cognitive goals, psychomotor goals, and affective goals. These three learning objectives are the most important considerations for teachers in planning and managing learning.

\section{a. Cognitive Goals}

Cognitive goals are related to behavioral aspects of thinking or intellectual behavior (Setyaningrum, 2021). Therefore, learning must reach the reasoning aspects of thinking of students. Bloom (Ibrahim, 1996: 72) explains six levels in the cognitive aspects, namely; (1) knowledge level uan, this level is related to the ability of students to recognize and remember learning material; (2) the level of understanding, which is related to the ability of students to understand and interpret the material studied in learning; (3) the level of application, which relates to the ability of students to use the knowledge gained in solving a problem; (4) the level of analysis, which refers to the ability of students to study and break down teaching materials into specific components; (5) the level of synthesis is related to the ability to combine various concepts through creative activities; and (6) evaluation level, namely the ability of students to formulate and provide an assessment of an event using certain norm standards.

b. Psychomotor objectives

Psychomotor objectives in learning to stimulate the active response of students' movements. Santrock (2007: 469) explains that this psychomotor aspect is not only related to athletics, but also with hand writing and word processing that involves certain movements. 


\section{Taufik Ridwan}

Furthermore, this psychomotor area is related to several levels, namely; 1 ) perception, relating to the activation of sensory functions, for example by recognizing colors; 2 ) readiness, related to the physical and emotional ability to perform movements; 3) guided response, related to the movements according to the examples given; 4) mechanical response, associated with independent movements that are no longer accompanied by examples; 5) complex responses, relating to the development of independent movements appropriately; 6) adaptation, relating to the ability to adapt movements to existing standards as a prerequisite, such as a competition; and 7) creativity, which relates to the ability to make new movements independently.

Based on this explanation, it can be concluded that the psychomotor goals in learning stimulate the physical potential of students and form their ability to move actively to independently create their own creative movements. Thus, learning must be seen as a physical and mental process that can make students active at these various levels.

\section{c. Affective Goals}

Learning objectives from an affective perspective lead to empathic formation that involves feelings or emotions which are the basis for students to grow into human beings who respect or respect others in their environment. Bloom (Winkel, 1987: 152) divides the affective domain into several levels, namely;

1) acceptance, related to the sensitivity of students to accept the teacher's explanation; 2) participation, related to the willingness or willingness to actively participate in an activity; 3 ) assessment and attitude determination, relating to the ability to judge something and determine an attitude on the results of the assessment of something; 4) organization, relating to the ability to shape the values of life guidelines that can be used as guidance in life; and 5) the formation of a pattern of life, related to the ability to appreciate the value of life which is then absorbed into personal property to regulate one's own life. Or in other words, Islam is able to draw wisdom from the reality of life or learn from the experience of wisdom stories. 


\section{Taufik Ridwan}

Based on this explanation, it can be concluded that the learning objectives affectively shape the empathic power of students so that they become individuals who are sensitive to the life around them (Saihu \& Umar, 2021). Students who have good affective will be able to organize various positive values in society and be able to distinguish negative values in their social environment. The positive values they understand will be absorbed as a value system for their attitude and formation in society.

\section{Learning Dynamics}

Learning as a process takes place dynamically because of various changing situations and conditions and can affect the quality of learning carried out. Of course, complex learning dynamics also have a big impact on students' abilities in learning outcomes. This is explained by Sudjana (2020: 148) that there are several things that influence each other in a learning process, namely; learning conditions, learning methods and learning outcomes.

\section{a. Learning Conditions}

Learning conditions can be explained by one of the factors that can affect the learning outcomes of teachers and students. This condition can be understood to come internally or externally. Internally, the determination of methods and the development of learning strategies carried out by the teacher can create a good learning condition and encourage students to be more motivated to follow learning. Disruption will occur internally if the teacher fails to determine the methods and strategies that are not appropriate, causing students to be bored with following ti learning.

Learning conditions can also be influenced externally, namely the influence that comes from the learning environment of students. There is a wider range of environmental conditions around the school and outside the school. Motorbike noise on the highway can interfere with learning concentration. More generally, such as the outbreak of the Covid-19 epidemic, it is an external condition that has a major influence on learning.

b. Learning methods

The learning method is one of the important elements in learning. Interesting learning dynamics are largely determined by the methods used 


\section{Taufik Ridwan}

by the teacher during the learning process. Therefore, the learning method is a decisive element in the learning system to make learning more interesting and make it easier for students to understand the contents of the teaching materials delivered by the teacher.

c. Learning Outcomes

Learning outcomes relate to all the achievements that can be used as a measure to assess the learning process as successful or not. This is one of the important elements at the end of the implementation of the learning process that can be recognized by students in the form of cognitive, affective, and psychomotor abilities. Thus, this learning outcome can be influenced by the series of learning carried out by the teacher, including the selection of methods and media used as learning instruments. All of these elements constitute a series of inseparable systems.

Based on this explanation, it can be concluded that aspects of learning conditions, learning methods and learning outcomes influence each other as a dynamic system. Apart from these three things, it can also be argued that other aspects that can affect the dynamics of learning such as the leadership of the principal, the availability of facilities and infrastructure and the availability of professional teachers in their fields.

D. Results

a. Continuous learning process

During the pandemic, teaching and learning activities (KBM) were faster, starting from 8 o'clock to 12 o'clock. And every day there were 3 lessons except on Thursdays there were additional lessons, namely Bk studies (counseling guidance) and for Friday the KBM was completed before prayer. Friday. the subject matter is in accordance with the applicable curriculum but there are parts or KD (Basic Competencies) that are missed.

learning using Microsoft Teams and the advantages of the system are being able to get attendance data automatically, if students do not attend meetings or KBM in the application then the student attendance score is automatic 0 . For monitoring implementation, namely by taking attendance via the goole form, there are also those who attend attendance through 


\section{Taufik Ridwan}

Microsoft Teams after the meeting. For evaluation, they are usually told to do the questions or not to re-read the material.

b. Teacher and parent support

Support from parents and teachers, namely by giving motivation to be more enthusiastic about learning and helping in having difficulties with the assignment or material presented. The learning facilities provided by the teacher / parents are printed books, internet cards, tablets (for those who don't have a smartphone) etc. Meanwhile, the infrastructure can be visited alone to the school as long as it follows the health protocol

The efforts of teachers / parents in encouraging learning improvements during the Covid-19 Pandemic are by providing motivation and delivering creative material, assigning students to fill out surveys to mention what online complaints and material complaints are provided and providing facilities and infrastructure that are useful for the role of the teacher / parents in providing good examples of learning during the Covid-19 Pandemic by providing assistance or encouragement in learning and making students become disciplined towards school protocols and health protocols.

c. Listening to information

Getting the latest information on material at home during the Covid-19 Pandemic is obtained from cellphones and also from neighbors who are in the same school. While the source of information. Material during the Covid19 Pandemic period was from friends and material sources of information got it sometimes from the PJ (person in charge) of the subjects of each class and sometimes got it directly from the teacher who delivered it in the group.

d. Active learning methodology

The learning method used during the Covid-19 pandemic The learning method was carried out online, namely by using the Microsoft Teams Zoom application, Google Meet, and others. Not all teachers use active learning methods, so there are some who give lectures, assign students to argue and discuss, there are also some that only deliver material 


\section{Taufik Ridwan}

e. Reflection of the problem.

Routine efforts to deal with learning problems during the Covid-19 pandemic are routinely carried out to find comfortable learning spots, listen to music instruments, and maintain sleep and eating patterns, while for teachers in dealing with problems of students who are less diligent, namely by contacting their parents via via Whast Group apps parents. If the child is still not doing the assignment, the teacher will contact the parents personally.

\section{f. Learning approaches}

Understanding of the learning approach used is by active student discussion through online through zoom media, Microsoft team. On the other hand, learning is carried out online, making students less familiar with the material being taught, students prefer to have an opinion or ask questions in the Drpida class online which are seen by more than one hundred people.

\section{g. Learn from each other}

The cultural routine of mutual learning between neighbors and friends only through the media Whast Aps, sometimes invites friends to play at home to learn material that is not understood, as it was calculated.

h. Think and act

In the learning process, always prioritize thinking and acting during the Covid-19 pandemic because thinking and acting are character education that must be applied daily.

i. Team Training

As a team, during the covid-19 pandemic period held training, for implementation as possible as usual but by keeping a distance and complying with health protocols. Meanwhile, as a team during the Covid-19 pandemic period, they invited expert teachers to maximize learning on certain days but not for all subjects. 


\section{Taufik Ridwan}

\section{Conclusion}

Based on the above changes, the following conclusions can be formulated. Learning is a process of interaction between teachers and students using various means of learning. Learning is carried out to achieve the goal of changing the behavior of students. Thus, in the learning process, the teacher's effort as an enlightening figure is a major aspect of the process of achieving change in learning. Therefore, teachers must be role models of behavior that will be emulated by students.

Theoretically, learning is carried out to achieve cognitive goals, namely thinking and intellectual behavior, psychomotor goals related to active physical movement responses of students, and affective goals, namely the empathic aspects of students. This learning objective will be achieved if it is supported by the dynamics of learning that are going well. Several factors that can influence the dynamics of learning are learning conditions, learning methods and learning outcomes.

The dynamics of learning in Indonesia are currently being disrupted externally by the Covid-19 outbreak crisis. Some of the impacts include; 1) schools are transferred to homes through an online learning process; 2 ) there is a transformation of technology-based learning media through the use of Wathshap Group, Zoom, Google Classroom, WebEx, Youtube, and TV channels; 3) adjustment of learning methods; 4) adjusting the learning evaluation to determine the standards for class promotion and graduation; and 5) demands for collaboration between parents of students at home as a substitute for teachers to control children's learning.

\section{References}

Al Hakim, Stai Luqman. (N.D.). Efektivitas Pembelajaran Bahasa Via Daring. Fakhruroji, Moch, Tresnawaty, Betty, Sumadiria, Haris, \& Risdayah, Enok. (2020). Strategi Komunikasi Publik Penanganan Covid-19 Di Indonesia: Perspektif Sosiologi Komunikasi Massa Dan Agama. Lp2m Uin Sunan Gunung Djati.

Ferdianti, Noviani. (2021). Analisis Penggunaan Komik Sebagai Media Pembelajaran Untuk Meningkatkan Hasil Belajar Peserta Didik Di Sekolah Dasar. Fkip Unpas.

Fikri, Muhammad, Faizah, Nadiyatul, Elian, Sefti Adelia, Rahmani, Rena, Ananda, Muhammad Zaki, \& Suryanda, Ade. (2021). Kendala Dalam Pembelajaran Jarak Jauh Di Masa Pandemi Covid-19: Sebuah Kajian 


\section{Taufik Ridwan}

Kritis. Jurnal Education And Development, 9(1), 145.

Jayul, Achmad, \& Irwanto, Edi. (2020). Model Pembelajaran Daring Sebagai Alternatif Proses Kegiatan Belajar Pendidikan Jasmani Di Tengah Pandemi Covid-19. Jurnal Pendidikan Kesehatan Rekreasi, 6(2), 190- 199.

Juwita, Juwita. (2021). Mengembangkan Kompetensi Profesional Widyaiswara Dalam Menghadapi Tantangan Pembelajaran Jarak Jauh (E-Learning) Dimasa Pandemi Covid 19. Syntax Literate; Jurnal IImiah Indonesia, 6(4), 1754-1772.

Mansyur, Abd Rahim. (2020). Dampak Covid-19 Terhadap Dinamika Pembelajaran Di Indonesia. Education And Learning Journal, 1(2), 113-123.

Novita, Monica Lisa, \& Kaligondang, S. D. N. (2021). Kemampuan Berpikir Kritis Dan Minat Belajar Siswa Dalam Pembelajaran Daring Dengan Model Pembelajaran Konstektual (Bernata Lari Dengan Molastek). Pembelajaran Di Masa Pandemi, Inovasi Tiada Henti (Kumpulan Best Practices Inovasi Pembelajaran, 94.

Nurillahi, Citra Asri. (N.D.). Kerjasama Antara Orang Tua Dan Guru Dalam Pendidikan Karakter Siswa Di Mts Jam'iyatul Khair Ciputat. Jakarta: Fitk Uin Syarif Hidayatullah Jakarta.

Prasetia, M.Arjun. (2021). Strategi Komunikasi Mts. T. I Kerkp Dalam Meningkatkan Jumlah Peserta Didik Dimasa Pandemi Covid-19. Iain Bengkulu.

Prasetyo, Teguh, \& Zulela, M. S. (2021). Proses Pembelajaran Daring Guru Menggunakan Aplikasi Whatsapp Selama Pandemik Covid-19. Jurnal Elementaria Edukasia, 4(1).

Rizky, Faris Surenda. (2021). Pengembangan Media Pembelajaran Pai Berbasis Android Dengan Menggunakan Aplikasi Inventor Kelas Xi Ips Di Sman 1 Seputih Mataram Kabupaten Lampung Tengah. Uin Raden Intan Lampung.

Saihu, Made, \& Umar, Nasaruddin. (2021). The Humanization Of Early Children Education. Al-Ishlah: Jurnal Pendidikan, 13(1), 173-185.

Setyaningrum, Desi Luh. (2021). Hubungan Tingkah Laku Dengan Kemampuan Berpikir Kritis Matematis. Semadik, 3(1), 377-386.

Ulfa, Andi Yurni. (2021). Dampak Pembelajaran Daring Masa Pandemi Covid- 19 (Studi Kasus Pada Orang Tua Peserta Didik): Andi Yurni Ulfa, Haerul Mutiah. Jurnal Pendidikan Sang Surya, 1(1), 22-30.

\section{Copyright holder: Taufik Ridwan (2019) \\ First publication right: Devotion - Journal of Community Service \\ This article is licensed under: (ㅇ) (1) (-)}

